\title{
Anlatıya Dahil Olmanın Hikâye Anlatıcılığına Etkisi: Unutulmaz Turizm Deneyimlerinin Aracı Rolü*
}

\author{
The Effect of Narrative Transportation on Storytelling: The Mediation Role of Memorable Tourism Experiences
}

\author{
Büşra KAYA**, Murat GÜMÜş*** \\ ** (Sorumlu Yazar) Lisansüstü Öğrenci, Ankara Hacı Bayram Veli Üniversitesi, Gölbaşı, 06830, Ankara. \\ E-posta: busra.kaya650@hbv.edu.tr \\ ORCID: 0000-0002-6133-7518 \\ *** Prof. Dr., Batman Üniversitesi, Yenişehir, 72000, Batman. \\ E-posta: muratgumus@yahoo.com \\ ORCID: 0000-0002-0761-6989
}

\section{MAKALE BILGILERI \\ Makale işlem bilgileri: \\ Gönderilme tarihi: 14 Ağustos 2020 \\ Düzeltme: 23 Aralık 2020 \\ Düzeltme: 25 Aralık 2020 \\ Düzeltme: 3 Ocak 2021 \\ Kabul: 5 Ocak 2021}

Anahtar sözcükler: Anlatıya ulaşım, Hikâye anlatıcılığı, Unutulmaz turizm deneyimi, Türkiye.

\section{ARTICLE INFO}

Article history:

Submitted: 14 August 2020

Resubmitted: 23 December 2020

Resubmitted: 25 December 2020

Resubmitted: 3 January 2021

Accepted: 5 January 2021

Key words: Memorable tourism experiences, Narrative transportation, Storytelling, Turkey.

\section{ÖZ}

Bu araştırmanın amacı anlatıya ulaşımın hikâye anlatıcılığına etkisinde unutulmaz turizm deneyimlerinin aracılık etkisini incelemektir. Günümüzde, postmodernizm ile deneyimsel pazarlama bağlamında unutulmaz turizm deneyimleri yaratmak oldukça önemli hale gelmiştir. Bu nedenle, hem hikâyelerin unutulmaz bir deneyim yaratma aracı olarak kullanılıp kullanılamayacağı hem de yaratılan bu deneyimin yeniden hikâyeleștirilerek anlatılıp anlatılmadığı bulgular sonucu tartıșılacaktır. Araștırma, nicel yöntem ve nedensel tarama modeli ile gerçekleștirilmiștir. Araștırmanın çalıșma evrenini, Türkiye'de yaşayan ve paket tur programlarına katılım sağlamış olan yerli turistler oluşmaktadır. Katılımcılardan toplam 250 geçerli veri elde edilmiştir. Elde edilen bu veriler; faktör analizi (AFA ve DFA), güvenirlik, regresyon ve aracılık etkisi analizleri yapılarak değerlendirilmiştir. Yapılan analizler sonucunda, anlatıya ulaşımın hikâye anlatıcılığı üzerindeki etkisinde, unutulmaz turizm deneyiminin aracı rolü ortaya koyulmuştur.

\section{Giriş}

Hikâye anlatıcılı̆̆ının, insanlığın var oluşu ile birlikte başladığı görüşü savunulmaktadır (Mathews ve Wacker 2009: 41). İnsanlık, var oluşunu, duygularını, bilgilerini ve davranışlarını hikâyeler aracılığ 1 ile aktarmaktadır. Her insan, yaşantısındaki belirli anılarından bahsederken,
"Size bir hikâyemi anlatmak isterim." ya da "Hayatımı yazsam roman olur." şeklinde ifadeler kullanmaktadır. Bunun nedeni, sosyal bir varlık olan insanların, belirli deneyimlerini paylaşmak yoluyla iletişim kurarak, duygularını ifade etmek istemesidir (Tekinalp ve Uzun 2019: 15). Turizm alanı, disiplinler arası yaklaşım ile ele alınmalıdır. Birçok disiplinden etkilenen bu alan- 
da özellikle pazarlama, yönetim-organizasyon, iletişim gibi disiplinler hikâyeleri çokça kullanmaktadır. Bu kullanım, bilinçli bir şekilde yönetilerek, stratejik avantajlar yaratabilmektedir. Kurumsal hikâyeler yaratmak, vizyonlarını açıklamak ya da örgütsel iletişimin düzenini sağlayıcı yazılı veya sözlü aktarımlar için hikâyelerin kullanımı, daha güçlü organizasyonlar yaratmak adına etkili araçlar olabilmektedir. Bunun yanı sıra, pazarlama alanında hikâyeler ile tüketicide duygusal öncelik algısı yaratılabilir ve satın alma niyeti güçlendirilebilir (Zhong vd. 2017). Üstelik sosyal medyada ağızdan ağıza pazarlamanın güçlendiği günümüzde, tüketiciyi hikâyenin bir parçası haline getirerek üretici-tüketici yaratmak mümkün olacaktır. Araştırmanın amacı, anlatıya ulaşımın (hikâye kullanımı) hikâye anlatıcılığına etkisinde unutulmaz turizm deneyimlerinin aracllık etkisini sınamaktır.

\section{KAVRAMSAL ÇERÇEVE}

\section{Anlatıya ulaşım}

Green ve Brock'a (2000) göre anlatıya ulaşım sağlanır ise hikâyelerin, bireyleri gerçek hayata dair inançları ile ilgili olarak etkilediği görülecektir. Her hikâye, temelde bir fikri, görüşü bildirmektedir. Bireyler, bu fikirleri, kendi hayatları ve deneyimleri ile karşılaştırdıklarında farklılıklar gözlemleyebilir. Bu doğrultuda, bireyler kendileri ile ilgili olarak bir farkındalık, aydınlanma yaşayarak değişime yönelebilmektedirler. Green ve Brock (2000) anlatıların özümsenmesini "ulaşım" ile adlandırmışlardır. Bu adlandırma, Gerrig'in (1993) yaptığı açıklamaya dayanmaktadır: "Gezgin (herhangi biri) bir yolculuğa çıkar ve bu yolculuk esnasında birçok ulaşım aracı ile karşılaşır. Bu ulaşım araçları gezgini gerçek dünyasından uzaklaştırır. Gerçek dünyasına döndüğünde ise bu ulaşım ile değişmiş olacaktır." Anlatıya ulaşım teorisi, bir bireyin özümsediği bir hikâye ile değişmesini, farkındalık yaşamasını ortaya koymaktadır.

Anlatıya ulaşım, üç faktörden meydana gelmektedir. Bunlar; bilişsel, duygusal ve özümseme faktörleridir. İnsanları etkileme ve ikna süreçlerinde bilişsel etkenler sıklıkla kullanılmaktadır (Cacioppo vd. 1996). İnsanlar, kendilerine ait benzer duyguların yaşandığı araçlara il- gi duyarak yönelecektir. Green ve Brock (2000), hikâyenin ne kadar özümsenir ise o kadar akılda kalıcı olacağını ortaya koymuştur.

\section{Hikâye Anlatıcılığı}

Hikâyeler, kişisel deneyimlerin yorumlanmasında kullanılabilecek en önemli araçlardandır (Servidio ve Ruffolo 2016). Bruner'e (2002: 64) göre, insanlar hikâyeler aracılığı ile geçmiş anılarını rehber ederek, geleceğini inşa etmektedir. Seyahat hikâyeleri, deneyimleri iyileştirmek adına önemli bir üründür ve iyi bir seyahat hikâyesi okuyucu/dinleyici üzerinde etkili olabilmektedir (Hsiao vd. 2013). Seyahat hikâyeleri, turizm faaliyetlerini deneyimleme, düşünme, anımsama ve paylaşma sürecinde de oldukça önemlidir (Tivers ve Rakic 2012). Mossberg (2008), çalışmasinda hikâyelerin deneyimleri anlamlı kıldığını vurgulamaktadır. Turizm hikâyelerinde turist, üretici-tüketici rolüyle hikâyelerin ortak yaratıcisıdır (Chronis 2012). Bu nedenle, hikâyeler turizm sektörünün merkezidir. Adaval ve Wyer (1998: 208), hikâyelerin deneyimleri yeniden hatırlamak için de etkili olduğunu yaptıkları çalışma ile ortaya koymuştur. Pizam (2010) yaptığ1 çalışmada, hikâyelerin turistler için gittikleri yer hakkında bilgi edinmek adına kullandığı bir araç olduğunu ortaya koymuştur. Yeni ve değişik bilgileri detaylandırmak ve akılda kalıcı olmasını sağlamak adına hikâyeler önem arz etmektedir. Bosangit vd. (2015) yaptıkları çalışmada, seyahat bloglarında yer alan hikâyelerin içeriklerini incelemişlerdir. Çalışma sonucuna göre, turistler seyahat hikâyelerini anlattıkları bloglarının merkezinde unutulmaz kişisel deneyimlerinin en anlamlı bölümlerine yer vermişlerdir.

\section{Unutulmaz Turizm Deneyimi}

Jefferies ve Lepp (2012: 38) unutulmaz turizm deneyimlerini, büyük oranda hatırlanabilen ve kişiler için özel ve duygu yüklü, yenilenme ve kendini geliştirmeye yönelik, hayatlarının değişmesinde rol oynayabilecek deneyimler olarak yorumlamaktadır. Kim, Ritchie ve McCormick (2012), bir seyahatin sonradan pozitif olarak hatırlanabilir olmasını unutulmaz turizm deneyimleri olarak yorumlamaktadır. Bu görüşün aksine Tung 
ve Ritchie (2011), unutulmaz turizm deneyimlerinin hem olumlu hem de olumsuz olarak hatırlanabileceğini ortaya koymuştur. Unutulmaz turizm deneyimleri, hafızada yer etmiş olan ve deneyimlendikten sonra dahi hatırlanan önemli olayların tamamı olarak tanımlanabilmektedir (Servidio ve Ruffolo 2016). Ek olarak, Knobloch, Robertson ve Aitken (2017), siradan bir deneyimin, turistte oluşan aidiyet hissi ile unutulmaz turizm deneyimine dönüşmesinin mümkün olduğunu belirtmektedir. Unutulmaz turizm deneyimleri hatırlanabilir olması nedeniyle, kişilerin yaşanan deneyim ve keyfin pekiştirmesine yardımcı olmaktadır (Kim, Ritchie ve McCormick 2012). Günümüzde turistler, ürünlerin ötesinde bu ürünlerin hikâyelerini deneyimlemek istemektedir ve bu nedenle unutulmaz turizm deneyimleri turistlerin, özünde ulaşmak istedikleri asıl son haline gelmiştir (Pizam 2010; Tung ve Ritchie 2011).

Unutulmaz turizm deneyimlerini ölçmek için yedi boyuttan oluşan yirmi dört maddelik bir ölçek geliştirilmiştir (Kim vd. 2012). Kim'e (2010) göre unutulmaz turizm deneyimleri için gerekli yedi faktör vardır. Bunlar; hedonizm (hazcilık), yenilenme (canlanma), yerel kültür (sosyal etkileşim), katılım, anlamlılık, bilgi ve yeniliktir.

\section{YÖNTEM}

Araştırma, nicel yönteme dayanmaktadır. Nicel yöntemlerden nedensel tarama modeli benimsenmiştir.

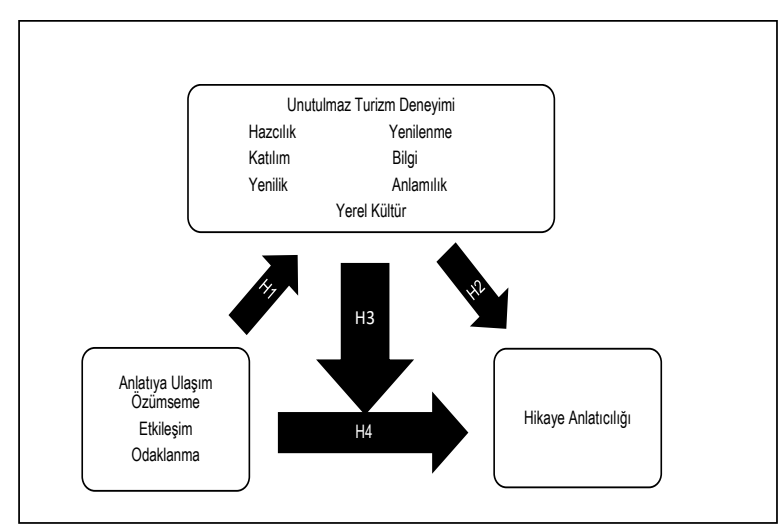

Şekil 1. Araştırma Modeli
Durumlar, kişiler ve nesneler karşısında elde edilen davranış ve algıların, ölçülebilir ya da gözlemlenebilir sonuçlarının kıyaslanmasında kullanılacak sayısal verilerin bir araya gelerek yorumlanmasını sağlayan araştırma türüne nicel araştırmalar denilmektedir (Kozak 2018: 55). Nedensel tarama modelinde ise neden-sonuç ilişkisi kurularak bu modelin nasıl yönlendirileceği ortaya konmaktadır (Kothari 2004: 35). Araştırmada neden-sonuç (anlatıya dahil olma- hikâye anlatımı yaratımı) ilişkisi kurulmuş ve unutulmaz turizm deneyiminin aracılığg dahil edilerek modelleştirilmiştir.

Günümüzde postmodernizm ve değişen kuşaklar ile birlikte gelen değişen beklentiler, deneyim yaratmayı zorunlu hale getirmektedir (Kotler vd. 2016). Turistlere, var olan hikâyelerden ya da hikâyeleştirilmiş içeriklerden unutulmaz bir deneyim sunulabilir mi? Sunulan hikâyeler yeniden bir hikâye yaratarak paylaşım yaratır mı? Sunulan hikâyeler, unutulmaz bir turizm deneyimi elde etmeyi sağlayarak, turistin yeniden hikâyeleştirerek anlatmasına neden olur mu? Söz konusu araştırma soruları ışığında araştırmanın hipotezleri aşağıdaki şekilde oluşturulmuştur:

$\mathrm{H}_{1}$ : Anlatıya ulaşımın, unutulmaz turizm deneyimleri üzerinde anlamlı bir etkisi vardır.

$\mathrm{H}_{2}$ : Unutulmaz turizm deneyimlerinin hikâye anlatıcılığını üzerinde anlamlı bir etkisi vardır.

$\mathrm{H}_{3}$ : Anlatıya ulaşımın hikâye anlatıcılığı üzerindeki etkisinde unutulmaz turizm deneyimlerinin anlamlı bir aracılık etkisi vardır.

$\mathrm{H}_{4}$ : Anlatıya ulaşımın, hikâye anlatıcılığı üzerinde anlamlı bir etkisi vardır.

\section{Evren ve Örneklem}

Araştırmanın evrenini paket tur programlarına katılım sağlayan yerli turistler oluşturmaktadır. Örneklem olarak çalışmanın başlangıcında, yedi bölgeden 60'ar olmak üzere toplam 420 veri ile analizi gerçekleştirmek hedeflenmiştir. Örneklem hesaplama tablolarında da yüzde 95 güven aralığında olan çalışmalar için 500.000 ve üzeri evren sayısını 384 örneklemin temsil edebileceği görülmektedir. Ancak çalışmanın yürütüldüğü 2020 yılının Mart ve Nisan aylarında yaşanan 
COVID-19 pandemisi nedeniyle veri toplama süreci kısıtlanmıştır. Marmara bölgesinde iki rehber aracılığ 1 ile yüz yüze toplanan 61 veriden sonra çevrimiçi anket formları kullanılmıştır. Kolayda örnekleme kullanılmıştır. Çevrimiçi anket ile gerçekleştirilen veri toplama sonucunda 192 veri elde edilmiştir. Toplamda 252 veri elde edilmiştir. Ancak yüz yüze toplanan verilerden ikisi eksik doldurulmuştur. Bu nedenle 250 geçerli veri ile analizler gerçekleştirilmiştir. Evreni temsil etme açısından yetersiz olan bu veri genellenebilirlik konusunda çalışmayı yetersiz kılmaktadır. Ancak Bryman ve Cramer (2001) örneklemin, anket formundaki madde sayısının en az beş katı olması gerektiğini belirtmiştir (Akt: Tavşancıl 2002). Bu bağlamda, araştırma verilerinin toplandığ1 anket formunda 40 madde bulması, 200 katılımcının yeterli olacağını göstermektedir. Genellenebilirlik konusunda yetersiz kalmasının yanında geçerli bir örneklem ile çalışma gerçekleştirilmiştir.

\section{Veri Toplama Araçları}

Araştırmanın verilerini elde etmek için üç fark11 ölçekten bir anket formu oluşturulmuştur. Çalışmada ilk ölçek; Kim, Ritchie ve Tung (2010), tarafından geliştirilen yedi boyut ve 24 soruluk unutulmaz turizm deneyimi ölçeğidir. İkinci ola- rak Green ve Brock (2000) tarafından geliştirilen üç boyut ve 11 soruluk anlatıya ulaşım ölçeği ve son olarak Zhong, Busser ve Baloğlu (2017) tarafından oluşturulan beş soruluk hikâye anlatıcılığ 1 ölçeği kullanılmıştır. Anlatıya ulaşım ve hikâye anlatıcılığı ölçek uyarlamaları için, dört uzman tarafından İngilizceden Türkçeye çeviri yaptırılmış sonrasında farklı dört uzman tarafından ters çeviri yapılmıştır. Elde edilen çeviriler sonucu araştırmacılar ölçeğin nihai haline karar vermişlerdir. Anket formunun ön testi için 50 katılımcı ile pilot çalışma gerçekleştirilmiştir. Araştırmada turistlerin katılım derecelerini belirlemek amacıyla beşli Likert ölçeği kullanılmıştır.

\section{Veri Analizi}

İstatistik paket programa girilen verilerde kodlama hatası yapılıp yapılmadı $\breve{g}$ kontrol edilerek hatalı kodlar düzeltilmiştir. Anket uygulaması sonucunda elde edilen verilerin analizinde çarpıklık basıklık analizi, faktör analizleri ve regresyon analizleri yapılmıştır.

Yukarıda yer alan Tablo 1'de ölçeklerin çarpıklık ve basıklık değerleri ele alınmıştır. Örneklem sayısının düşük olduğu analizlerde, daha sağlık1ı sonuçlar için bootstrap uygulanabilmektedir (Ankaralı, Yazıcı ve Ankaralı 2009). Bu nedenle, 250 adet örneklem için bootstrap (1000) uygula-

Tablo 1. Normallik Dağılım Sonuçları (Çarpıklık-Basıklık)

\begin{tabular}{|c|c|c|c|}
\hline Hikâye & Normal & \multicolumn{2}{|c|}{ Bootstrap } \\
\hline Anlatıcılığı & Değer & Minimum Değer & Maksimum Değer \\
\hline Çarpıklık &,- 899 & $-1,171$ &,- 593 \\
\hline Basıklık & 1,021 & , 143 & 1,890 \\
\hline Anlatıya & Normal & \multicolumn{2}{|c|}{ Bootstrap } \\
\hline Ulaşım & Değer & Minimum Değer & Maksimum Değer \\
\hline Çarpıklık &,- 580 &,- 861 &,- 261 \\
\hline Basıklık & ,582 &,- 140 & 1,432 \\
\hline \multirow[t]{2}{*}{ Unutulmaz Turizm Deneyimi } & Normal & \multicolumn{2}{|c|}{ Bootstrap (1000) } \\
\hline & Değer & Minimum Değer & Maksimum Değer \\
\hline Çarpıklık & $-1,409$ & $-1,857$ &,- 510 \\
\hline Basıklık & 4,579 & 658 & 6,361 \\
\hline
\end{tabular}


narak çarpıklık-basıklık testi ile ölçeğin normalliği sınanmıştır. Çarpıklık ve basıklık, yüzde 95 güven aralığında $+1,5$ ile $-1,5$ değer aralığında olmalıdır (Tabachnick ve Fidell 2013). Elde edilen bulgulara göre, unutulmaz turizm deneyimi için basıklık değeri bu durumu sağlamamaktadır. Ancak bu ölçeğin çarpıklık değerinin ve diğer ölçeklerin çarpıklık-basıklık değerlerinin beklenen aralıkta olması nedeni ile normal dağılımda olduğu varsayılarak analizler gerçekleştirilmiştir.

"Unutulmaz Turizm Deneyimi” ölçeği daha önce Türkçe diline uyarlanarak uygulanmıştır. Bu nedenle DFA ile geçerlilik analizi yapılmıştır. Aşağıda yer alan Tablo 2'de ölçeğe ilişkin uyum iyiliği bulgularına yer verilmiştir.

Unutulmaz Turizm Deneyimini oluşturan maddeler üzerinde doğrulayıcı faktör analizi (DFA) yapılmış, yedi ana faktör olan hazcılık, yenilenme, yerel kültür, katılım, anlamlılık, bilgi ve yenilik ile 24 madde analiz edilmiştir. Yapılan analiz sonucunda, uyum iyiliği değerlerini iyileştirmek adına, katılım faktörüne ait MTE13 ile MTE14 maddeleri ve yenilik boyutuna ait MTE21 ile MTE22 maddeleri arasında kovaryans oluşturularak modifikasyon gerçekleştirilmiştir. Bu işlem sonrası, analiz bulguları incelendiğinde ise modelin uyum iyiliği indeksleri Tablo 2'de görüldüğü gibi standart değerlerde çıkmıştır. x2/ df $(2,634)$ değerinin 3 'ten küçük, CFI $(0,91)$ ve IFI $(0,91)$ uyum iyiliği değerlerinin ise 0,90 'dan yüksek olduğu görülmektedir. Bu değerler ölçeğin uyumunun geçerli olduğunu ifade etmektedir. RMSEA değerinin 0,08 (Çekici vd. 2018) olması mükemmel uyumu gösterirken, NFI değerinin $(0,86), 0,85$ ve üzerinde olması ölçeğin kabul edilebilir değerler içinde olduğunu göstermektedir (Hu ve Bentler 1999).

Unutulmaz Turizm Deneyimi ölçeğinin alt boyutları da ele alınarak güvenilirlik analizi yapılmıştır. Yukarıda yer alan Tablo 3'te analiz bulgularına yer verilmiştir. Ayırt edici geçerlilik incelenirken kullanılan yöntemlerden biri de Fornell ve Larcker (1981) tarafından formülleştirilen Çıkarılan Ortalama Varyans (ÇOV) değeridir. ÇOV standardize edilmiş faktör yüklerinin kareleri toplamının madde sayısına bölünmesiyle bulunur ve bu değerin $\geq 0,50$ olması arzu edilir (Şencan 2005). Tablo 3'te görüldüğü gibi 0,50'nin altında açıklanan bir ÇOV değeri olmadığı için ayırt edici geçerliliği de sağlamaktadır.

Ayrıca, ayırt edici geçerlilik için farklı faktörlerin korelasyon değerlerinin, her bir faktör için bulunan ÇOV değerinin karekökünden düşük olması beklenmektedir. Ancak bu durum gerçekleşir ise ayırt edici geçerlilik sağlanmış olacaktır (Fornell ve Lacker 1981). Sonuç olarak Tablo 3'te görüldügü üzere bütün ÇOV değerlerinin karekökü, faktörler arasındaki korelasyon değerlerinden büyüktür. Bu bağlamda; ölçeğin ayırt edici geçerliliği de sağladığı söylenebilir.

Unutulmaz turizm deneyimi ölçeğinden sonra, ilk kez uyarlanan anlatıya ulaşım ve hikâye anlatıcılığı ölçekleri için açımlayıcı faktör analizi (AFA) gerçekleştirilmiştir. Anlatıya ulaşım ölçeğinde öncelikli olarak ikinci, beşinci ve dokuzuncu maddeler ters kodlu olduğu için düzeltmesi

Tablo 2. Unutulmaz Turizm Deneyim Ölçeği Uyum İyiliği Değerleri

\begin{tabular}{lcc}
\hline Uyum Iyiliği Ölçütleri & Unutulmaz Turizm Deneyimi Uyum- Iyiliği Değerleri & $\begin{array}{c}\text { Standart } \\
\text { Değerler }\end{array}$ \\
\hline CMIN/DF $\left(\mathrm{x}^{2} / \mathrm{df}\right)$ & 2,634 & $\leq 3$ veya $\leq 5$ \\
\hline RMSEA &, 08 & $\leq, 08$ veya, 10 \\
\hline CFI &, 91 & $\geq, 90$ \\
\hline IFI & 91 & $\geq, 90$ \\
\hline NFI &, 86 & $\geq, 90$ veya ,85 \\
\hline
\end{tabular}


Tablo 2. Unutulmaz Turizm Deneyim Ölçeği Uyum İyiliği Değerleri

\begin{tabular}{|c|c|c|c|c|c|}
\hline \multirow{2}{*}{$\begin{array}{l}\text { Faktörler ve Ifadeler } \\
\text { Unutulmaz Turizm Deneyimi }\end{array}$} & \multirow[t]{2}{*}{ Faktör Yükü } & \multirow[t]{2}{*}{ t Değerleri } & & Birleşik Güvenilirlik & \multirow{3}{*}{$\begin{array}{l}\text { çOV } \\
607\end{array}$} \\
\hline & & & & & \\
\hline Ölçeği & & & & 973, & \\
\hline 1.Faktör: Hazcılık & & & & 870 & 627 \\
\hline MTE1 & ,830 & 8,975 & & & \\
\hline MTE2 & ,719 & 9,705 & & & \\
\hline MTE3 & ,774 & 8,773 & & & \\
\hline MTE4 & 839 & 10,138 & & & \\
\hline 2.Faktör: Yenilenme & & & & ,841 & ,571 \\
\hline MTE5 & 687 & 8,764 & & & \\
\hline MTE6 & ,715 & 9,072 & & & \\
\hline MTE7 & 817 & 5,950 & & & \\
\hline MTE8 & 797 & 8,343 & & & \\
\hline 3.Faktör: Yerel Kültür & & & & 826 & ,614 \\
\hline MTE9 & ,859 & 9,191 & & & \\
\hline MTE10 & ,771 & 8,554 & & & \\
\hline MTE11 & ,716 & 9,626 & & & \\
\hline 4.Faktör: Katılım & & & & ,823 & 609 \\
\hline MTE12 & ,743 & 7,060 & & & \\
\hline MTE13 & 844 & 8,052 & & & \\
\hline MTE14 & 751 & 10,288 & & & \\
\hline 5.Faktör: Anlamlılık & & & & ,847 & 651 \\
\hline MTE15 & 883 & 8,879 & & & \\
\hline MTE16 & 855 & 8,296 & & & \\
\hline MTE17 & 667 & 9,848 & & & \\
\hline 6.Faktör: Bilgi & & & & 830 & ,621 \\
\hline MTE18 & 805 & 9,416 & & & \\
\hline MTE19 & 832 & 8,624 & & & \\
\hline MTE20 & ,724 & 8,559 & & & \\
\hline 7.Faktör: Yenilik & & & & ,841 & ,571 \\
\hline MTE21 & 689 & 9,691 & & & \\
\hline MTE22 & ,765 & 10,127 & & & \\
\hline MTE23 & ,773 & 9,964 & & & \\
\hline MTE24 & ,793 & 8,168 & & & \\
\hline Hazcılık & Yenilenme & Yerel Kültür & Katılım & Anlamlılık Bilgi & Yenilik \\
\hline 1-Hazcilık & & & & & \\
\hline 2-Yenilenme & ,755 & & & & \\
\hline 3-Yerel Kültür & ,295 & ,783 & & & \\
\hline 4-Katılım & ,317 & ,469 & ,780 & & \\
\hline 5-Anlamlılık & 291 & 465 & ,233 & ,806 & \\
\hline 6-Bilgi & 296 & ,406 & 229 & 275 , 788 & \\
\hline 7-Yenilik & 232 & ,343 & 196 & 217 & ,755 \\
\hline
\end{tabular}


yapılmıştır. Hem anlatıya ulaşım hem de hikâye anlatıcılığ 1 için her maddenin faktör yükü beklenen değer $(0,40)$ üzerindedir. Bu nedenle tüm maddeler geçerli faktör yükünde olduğu görülmektedir (Tablo 4).

Bir ölçeğin geçerliliğini ortaya koymak için Kaiser-Meyer-Olkin (KMO) değerinin ölçülmesi gerekmektedir. Bu değerin en az 0,5 olması beklenir. 0,5 ile 0,7 arasındaki değerler yeterli olarak nitelendirilirken, 0,7 değerinin üzerindekiler için iyi bir geçerlilik sağladığı söylenmektedir (Can 2018: 325). Aşağıda yer alan Tablo 4'te anlatıya ulaşım ölçeğinin 0,811 KMO değeri ile iyi bir geçerlilik sağladığı görülmektedir. Hikâye anlatıc1- lığı ölçeğinin ise 0,757 KMO değeri ile iyi bir geçerlilik sağladığı görülmektedir.

Geçerlilik testlerinin yanı sıra ölçeğin ve alt boyutlarının güvenirlik analizi incelenmiştir (Bkz. Tablo 4). Özümseme boyutu 0,886; odaklanma boyutu 0,757 olarak tespit edilmiştir. Çıkan sonuca göre, etkileşim boyutuna ait madde sekizin değerleri olumsuz etkilediği görülmüş ve analizlerden çıkartılmıştır. Olması beklenen her bir faktörde en az üç maddenin olmasıdır. Ancak bu gibi yapısal sorunlar olduğunda iki maddeli faktörler de kabul görmektedir (Çakır 2014). Buna dayanarak eksiltilen maddeden sonra "Etkileşim" boyutunun güvenilirlik değerinin 0,786

Tablo 4. Anlatıya Ulaşım ve Hikâye Anlatıcılı̆̆ı Geçerlilik ve Güvenilirlik Analiz Sonuçları

\begin{tabular}{|c|c|c|c|c|c|c|}
\hline $\begin{array}{c}\text { Faktörler ve } \\
\text { ifadeler }\end{array}$ & $\begin{array}{l}\text { KMO } \\
\text { Değeri }\end{array}$ & $\begin{array}{l}\text { Faktör } \\
\text { Yükü }\end{array}$ & $\begin{array}{c}\text { Öz } \\
\text { Değer }\end{array}$ & $\begin{array}{l}\text { Açıklanan } \\
\text { Varyans \% }\end{array}$ & $\begin{array}{c}\text { Toplam } \\
\text { Varyans \% }\end{array}$ & $\begin{array}{l}\text { Cronbach } \\
\text { Alpha (a) }\end{array}$ \\
\hline Anlatıya Ulaşım Ölçeği & 0,811 & & & & &, 706 \\
\hline 1.Faktör: Özümseme & & & 4,249 & 38,624 & 38,624 & ,886 \\
\hline NT1 & & ,773 & & & & \\
\hline NT3 & & ,638 & & & & \\
\hline NT4 & & 800 & & & & \\
\hline NT6 & & 669 & & & & \\
\hline NT7 & & ,698 & & & & \\
\hline 2. Faktör: Etkileşim & & & 2,469 & 22,448 & 61,072 & ,786 \\
\hline NT10 & & ,761 & & & & \\
\hline NT11 & & ,765 & & & & \\
\hline 3.Faktör: Odaklanma & & & 1,082 & 9,833 & 70,905 & ,757 \\
\hline NT2 & &, 571 & & & & \\
\hline NT5 & & ,807 & & & & \\
\hline NT9 & & ,781 & & & & \\
\hline Hikâye Anlatıcılığı Ölçeği & 0,757 & & 3,232 & 64,633 & 64,633 & ,863 \\
\hline ST1 & & ,690 & & & & \\
\hline ST2 & & ,684 & & & & \\
\hline ST3 & & ,567 & & & & \\
\hline ST4 & & ,618 & & & & \\
\hline ST5 & & 673 & & & & \\
\hline
\end{tabular}


olduğu görülmüştür. Ölçeğin genel Cronbach's Alpha değeri ise, 0,706 olarak görülmektedir. Bu sonuçlara göre, ölçek alt boyutlarının tamamı 0,60 ve 0,90 aralığında olduğundan oldukça güvenilir olarak yorumlanmıştır (Özdamar 1999; Akt. Tavşancıl 2006:29) Hikâye anlatıcılı̆̆ı̈ ölçeğinin genel Cronbach's Alpha değeri ise, 0,863 olarak görülmektedir. Bu sonuca göre, ölçek değeri, 0,60 ve 0,90 aralığında olduğundan oldukça güvenilir olarak yorumlanmıştır (Özdamar 1999; Akt. Tavşancıl 2006:29). Anlatıya ulaşım ve hikâye anlatıcılı̆̆ ölçeklerinde tüm faktör yükleri 0,50'nin üstünde gözlemlenmiştir. Bu nedenle ölçeğin faktör yükleri açısından da geçerliliği sağlanmaktadır.

\section{BULGULAR}

Araştırma hipotezleri doğrultusunda doğrudan regresyon ve process eklentisi ile aracilık etkisi analizleri yapılmıştır. Tüm analizler için değişkenlerin ve alt boyutların ortalamaları kullanılmıştır. Tablo 5'te anlatıya ulaşımın, unutulmaz turizm deneyimi üzerindeki etkisi incelendiğinde katsayı değerinin 0,67 olduğu görülmektedir. Bu etki, $p \leq 0,05$ düzeyinde anlamlıdır. Bu bağlamda; anlatıya ulaşımın, unutulmaz turizm deneyimi üzerinde anlamlı bir etkisi olduğu görülmektedir. Bu bulgulara dayanarak, H1: "Anlatiya ulaşım, unutulmaz turizm deneyimine anlamlı etki etmektedir." hipotezi desteklenmiştir. Bu etkinin hangi faktörden geldiğine bakıldığında ise anlatıya ulaşım özelinde, unutulmaz turizm deneyimine etki eden en önemli faktörün özümseme olduğu görülmektedir. Bu durumu, hikâyelerin, bilişsele kıyasla daha çok duygusal etki yaratması ile açıklamak mümkündür. Özümseyerek içselleştirilmemiş bir anlatı, deneyimi unutulmaz kılmayacaktır. Bunun yanı sıra odaklanma faktörünün; hazcllık (Sig=0,439), yenilenme (Sig=0,298), yerel kültür (Sig=0,058) ve katılım (Sig=0,528) faktörlerine anlamlı bir etkisinin olmadığ 1 görülmüştür. Turistler, yalnızca odaklanarak bir hikâyeye ulaşım sağladığında deneyimden haz alma, katılım sağlamış olma, yerel kültürü tanıma (sosyalleşme) ya da yenilenmişlik hissi çıktılarını elde etmemektedir.
Tablo 5'te yer alan unutulmaz turizm deneyiminin, hikâye anlatıcıllğı üzerindeki etkisi incelendiğinde katsayı değerinin 0,61 olduğu görülmektedir. Bu etki, $\mathrm{p} \leq 0,05$ düzeyinde anlamlıdır. Bu bağlamda; unutulmaz turizm deneyiminin, hikâye anlatıcılığını üzerinde anlamlı bir etkisi olduğu görülmektedir. Bu bulgulara dayanarak, H2: "Unutulmaz turizm deneyiminin, hikâye anlatıcılığı üzerinde anlamlı bir etkisi vardır." hipotezi desteklenmiştir. Hikâye anlatıcılığına en çok etki eden faktör yenilenme $(0,559)$ olmuştur. Bu değere en yakın faktör ise hazcilık $(0,557)$ olarak görülmektedir. Bu durumda, turistlerin en çok, yenilendiği ve haz duyduğu deneyimleri paylaştığı söylenebilmektedir. Tüm faktörler önemli düzeyde etkili olmasının yanında en düşük değerin yenilik $(0,444)$ faktörüne ait olduğu ortaya konmuştur. Bu durumda; turistlerin, yeni bir olay/yer/mal ya da hizmet deneyiminden çok, edindiği deneyimin kendisinde uyandırdığ nilenme hissini paylaşım için daha anlamlı bulduğunu söylemek mümkündür.

Tablo 5'te yer alan analiz bulguları incelendiğinde anlatıya ulaşımın hikâye anlatıcılı̆̆ına olan etkisinde unutulmaz turizm deneyiminin arac1lık etki oranı 0,27 olarak gözlemlenmiştir. Analizde, Hayes'in (2013) program için verdiği analiz modellerinden Basit Aracılık Modeli (4.Model) kullanılmıştır. Hayes'e (2013) göre, bu analiz ile modeldeki aracılık etkisinin bootstrap (5000) yöntemi kullanılarak yüzde 95 güven aralığında sınanması sağlanmaktadır ve çıkan değerler sıfırın üstünde olmalıdır. Sıfırın üstünde çıkan değerler modelde aracılık etkisinin olduğunu göstermektedir. Bu analiz sonucunda, yüzde 95 güven aralığında çıkan istatistiki değerler 0,180 ile 0,363 arasındadır. Bu bağlamda; anlatıya ulaşımın hikâye anlatıcılığına olan etkisinde unutulmaz turizm deneyimlerinin anlamlı bir aracılık etkisi olduğu görülmektedir. Bu bulgulara dayanarak, H3: "Anlatıya ulaşımın hikâye anlatıcılığ üzerindeki etkisinde unutulmaz turizm deneyimleri anlamlı bir aracı etki yaratmaktadır." hipotezi desteklenmiştir.

Tablo 5'te yer alan anlatıya ulaşımın, hikâye

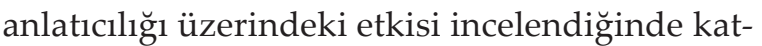
sayı değerinin 0,46 olduğu görülmüştür. Bu etki 
Tablo 5. Hipotezlere Ait Analiz Bulguları

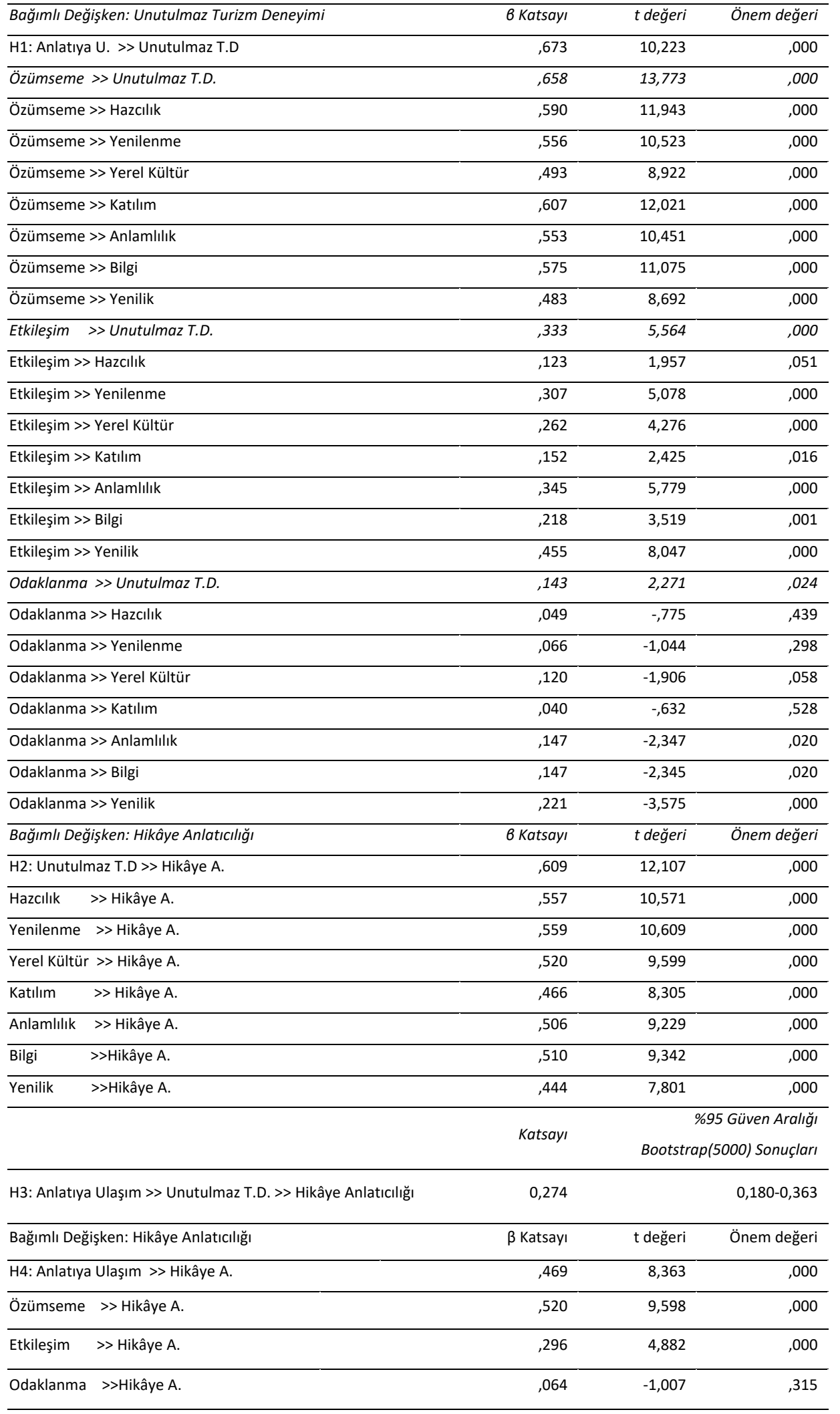


$p \leq 0,05$ düzeyinde anlamlıdır. Bu bağlamda; anlatıya ulaşımın, hikâye anlatıcılığı üzerinde anlamlı bir etkisi olduğu görülmektedir. Bu bulgulara dayanarak, H4: "Anlatıya ulaşımın hikâye anlatıcılığı üzerinde anlamlı bir etki vardır." hipotezi desteklenmiştir. Anlatıya ulaşıma bağlı faktörler incelendiğinde, özümseme $(0,520)$ faktörünün en çok etki eden faktör olduğu görülmektedir. Bunun aksine, odaklanma faktörü $(\operatorname{Sig}=0,315)$ anlamsızdır. Bu bağlamda; turistler, özümsedikleri hikâyeleri paylaşma eğilimindeyken odaklanmayı anlamsız değerlendirmiştir. Bunun nedeni, insanların şehrin kaosundan ve yoğunluğundan kaçmak istemeleri ve zihinsel odaklanma yerine duygularına hitap edecek deneyimleri tercih etmeleri olabilmektedir. Sonuç olarak hikâyeleri özümseyen, duygusal bir bağ kuran turistler bu hikâyeleri paylaşma eğiliminde olmaktadır.

\section{SONUÇ VE ÖNERILER}

Araştırma sonucunda, anlatıya ulaşımın unutulmaz turizm deneyimini etkilediği görülmüştür. Uygur vd. (2017), yaptıkları kavramsal çalışmada, turizm endüstrisinin hedef kitlesi için unutulmaz turizm deneyimlerine yönelik, hikâyelerin kullanımının önemli olduğuna dikkat çekmişlerdir. Bu bağlamda, araştırmanın sonucu ile alanyazında yer alan bu çalışmaların sonuçları örtüşmektedir. Unutulmaz turizm deneyiminin hikâye anlatıcılığına etkisi olduğu görülmüştür. Alanyazın incelendiğinde bu etki, Zhong vd. (2017) ile Bose ve Biju'nun (2020) çalışmaları ile ilişkilidir. Zhong vd. (2017) çalışmalarından unutulmaz turizm deneyimlerinin, hikâye anlatıcılığını etkilediğini ortaya koymuştur. Bose ve Biju (2020) ise unutulmaz turizm deneyimlerinin ağızdan ağıza pazarlamaya etkisini ortaya koymuştur. Anlatıya ulaşımın, hikâye anlatıcılığ1 etkisi üzerinde unutulmaz turizm deneyiminin aracılık rolü de araştırma sonunda ortaya koyulmuştur. Yılmaz (2016), yaptığı çalışmada hikâyelerin, unutulmaz turizm deneyimine etki ettiğini ve turistin bu deneyimi paylaşma eğiliminde olduğunu ortaya koymuştur. Buna ek olarak; Delgadillo ve Escalas (2004), yaptıkları çalışmada hikâyelerin, bellekte yer ederek tüketici davranışını etkilediğini belirtmişlerdir. Yazarlar, bu durumun ağıdan ağıza pazarlamaya zemin hazırladığını ve ağızdan ağıza pazarlamanın da anlatı yapısına sahip olması nedeniyle bir hikâye anlatıcılığı şekli olduğunu belirtmektedirler. Buna bağlı olarak; alanyazında, doğrudan aracılık etkisi incelenmemiş olsa da doğrulanan bu etkiye ilişkin benzer çıkarımların olduğu çalışmalar yer almaktadır. Son olarak anlatıya ulaşım da hikâye anlatıcılığına etki etmektedir. Alanyazında doğrudan anlatıya ulaşımın hikâye anlatıcıllı̆ına etkisine değinilmese dahi araştırma sonucuyla örtüşen bilgilere rastlamak mümkündür. Örneğin; Dönmez (2015) efsanelerin, ağızdan ağıza aktarılarak bir hikâye anlatıcılığı yarattığını ve bu anlatıların güçlü ikna edici özellikte olduğunu vurgulamıştır. Araştırmanın temelini oluşturan, turistlerin hikâye anlatıcılığ 1 sürecinde unutulmaz turizm deneyimlerinin aracı etkisi, doğrulanmıştır. Bu temele dayanarak, turizm hizmeti sunan tüm kurumlar, işverenler ve hatta çalışanlar bilinçli bir şekilde turisti hikâye yaratabileceği bir deneyime çekmeli yahut unutulmaz deneyimler adına hikâyeler sunmalıdır. Bu şekilde turist, yaşadığı deneyimi başkaları ile paylaşma niyetine yönelecektir. Bu araştırma sonucuna göre; hikâyeler turist davranışlarını, turist deneyimlerini ve turizm pazarlamasını etkileyen önemli bir iletişim aracıdır. Aynı zamanda, turistlerin deneyimlerini hikâyeler aracılığı ile sunması, turisti aktif bir turizm aracına da dönüştürmekte ve turizm pazarlamasında güçlü bir anlatıcı haline getirmektedir.

Bu çalışma ile alanyazında yeterince çalışılmamış bir alanda eksikliğin giderilmesi ve gelecek çalışmalara yol gösterici olması amaçlanmıştır. Akademik anlamda, günümüzde popüler olan bir konuda rehberlik edecek bulguların sunulması çalışmayı önemli kılmaktadır. Sektörel anlamda ise gerek işletmeler gerekse destinasyonlar açısından hikâyelerin ve hikâyeleştirmenin kullanılması gerektiği ortaya çıkmıştır. Çalışma bulgularına dayanarak bazı sektörel öneriler sunulabilmektedir:

Türkiye, birçok medeniyete ev sahipliği yapmış bir ülkedir. Bu nedenle, oldukça fazla kültüre ait hikâyelere sahiptir. Hikâyesi olan destinasyonların önemi arttırılmalı ve hikâyesi olabildiğince 
kişiye aktarılmalıdır. Bu durum yalnızca turizm pazarlaması anlamında önem taşımayacak, aynı zamanda somut olmayan kültürel mirasın da gelecek nesillere aktarımı ile sürdürülebilirliğini arttıracaktır.

Seyahat acenteleri paket tur programları düzenlerken, hikâye içeriğine yönelik oranı arttırmalı ve hatta tur programının tanitımını hikâyeler üzerinden gerçekleștirmelidir. Bu hem turlara çekimi arttıracak hem de tur bitiminde turistin başkaları ile deneyimini paylaşmasını sağlayacaktır. Gerçekleştirilen araştırma, kabul edilir olmasına rağmen Koronavirüs salgını nedeniyle az sayıda veriden meydana gelmiştir. $\mathrm{Bu}$ nedenle, daha fazla katılımcı ile yinelenebilir ve bulgular sinanabilir. Profesyonel turist rehberlerinin aktardığ 1 hikâyeler ile ilgili bir vaka çalışması yapılabilir. Bu hikâyelerin, turistin tutum ve davranışlarına etkisi ya da rehberin hikâye anlatıcılığındaki anlatıcı rolünün etkisi incelenebilir.

\section{KAYNAKÇA}

Adaval, R. ve Wyer, Jr. R. S. (1998). The Role of Narratives in Consumer Information Processing, Journal of Consumer Psychology, 7 (3): 207-245.

Ankaralı, H., Yazıc1, A. C. ve Ankaralı, S. (2009). A Bootstrap Confidence Interval for Skewness and Kurtosis and Properties of t-test in Small Samples from Normal Distribution, Medical Journal of Trakya University/Trakya Üniversitesi Tıp Fakültesi Dergisi, 26 (4): 297-305.

Bosangit, C., Hibbert, S. ve McCabe, S. (2015). If I was Going to Die I Should at Least be Having Fun: Travel Blogs, Meaning and Tourist Experience, Annals of Tourism Research, 55: 1-14.

Bose, J. ve Biju, M. K. (2020). Accommodation Preferences, Memorable Tourism Experience and its Outcomes - A Comparative Study on Homestays vs Other Accommodation among Tourists, Test Engineering \& Management, 82: 13022-13035.

Bruner, J. (2002). Making Stories: Law, Literature, Life, 23.

Cacioppo, J. T., Petty, R. E., Feinstein, J. A. ve Jarvis, W. B. G. (1996). Dispositional Differences in Cognitive Motivation: The Life and Times of Individuals Varying in Need for Cognition, Psychological Bulletin, 119 (2): 197.

Can, A. (2018). SPSS ile Bilimsel Araştırma Sürecinde Nicel Veri Analizi. Ankara: Pegem Akademi.

Chronis, A. (2012). Between Place and Story: Gettysburg As Tourism Imaginary, Annals of Tourism Research, 39 (4): 1797-1816.

Çakır, A. (2014). Faktör Analizi. Doktora Raporu. İstanbul: İstanbul Ticaret Üniversitesi, Sosyal Bilimler Enstitüsü.
Çekici, F., Gördesli, M. A., Arslan, R., Sünbül, Z. A. ve Malkoç, A. (2018). The Psyhometric Properties of Mindfulness in Parenting Questionnaire (MIPQ) in Turkish Sample, European Journal of Education Studies, 5 (5): 175188

Delgadillo, Y. ve Escalas, J. E. (2004). Narrative Word-OfMouth Communication: Exploring Memory and Attitude Effects of Consumer Storytelling, Acr North American Advances, 31:186-192.

Dönmez, M. (2015). Pazarlama İletişiminde Transmedya Uygulamaları: Örnek Olay İncelemeleri (Basılmamış Doktora Tezi) Konya: Selçuk Üniversitesi Sosyal Bilimler Enstitüsü.

Fornell, C. ve Larcker, D. F. (1981). Evaluating Structural Equation Models with Unobservable Variables and Measurement Error, Journal of Marketing Research, 18 (1): 3950.

Gerrig, R. J. (1993). Experiencing Narrative Worlds: on The Psychological Activities of Reading. Londra:Yale University Press.

Green, M. C. ve Brock, T. C. (2000). The Role of Transportation in The Persuasiveness of Public Narratives, Journal of Personality and Social Psychology, 79 (5): 701.

Hayes, A. F. (2013). Introduction to Mediation: A Regression-Based Approach. New York: Guilford Press.

Hsiao, K. L., Lu, H. P. ve Lan, W. C. (2013). The Influence of The Components of Storytelling Blogs on Readers' Travel Intentions, Internet Research, 23 (2): 160-182.

Hu, L. T. ve Bentler, P. M. (1999). Cutoff Criteria for Fit Indexes in Covariance Structure Analysis: Conventional Criteria Versus New Alternatives. Structural Equation Modeling, A Multidisciplinary Journal, 6 (1): 1-55.

Jefferies, K. ve Lepp, A. (2012). An Investigation of Extraordinary Experiences, Journal of Park \& Recreation Administration, 30 (3): 37-51.

Kim, J. H. (2010). Determining the Factors Affecting The Memorable Nature of Travel Experiences, Journal of Travel $\mathcal{E}$ Tourism Marketing, 27 (8): 780-796.

Kim, J. H., Ritchie, J. B. (2014). Cross-Cultural Validation of A Memorable Tourism Experience Scale (MTES), Journal of Travel Research, 53 (3): 323-335.

Kim, J. H., Ritchie, J. R. ve Tung, V. W. S. (2010). The Effect of Memorable Experience on Behavioral Intentions in Tourism: A Structural Equation Modeling Approach, Tourism Analysis, 15 (6): 637-648.

Kim, J.-H., Ritchie, JRB ve McCormick, B. (2012). Development of A Scale to Measure Memorable Tourism Experiences, Journal of Travel Research, 51 (1): 12-25.

Knobloch, U., Robertson, K. ve Aitken, R. (2017). Experience, Emotion, and Eudaimonia: A Consideration of Tourist Experiences and Well-Being, Journal of Travel Research, 56 (5): 651-662.

Kothari, C. R. (2004). Research Methodology: Methods and Techniques. New Delhi: New Age International.

Kotler, P., Kartajaya, H. ve Setiawan, I. (2016). Marketing 4.0: Moving From Traditional To Digital. New Jersey: John Wiley \& Sons. 
Kozak, M. (2018). Bilimsel Araștırma: Tasarım, Yazım ve Yayım Teknikleri. Ankara: Detay Yayıncilık.

Mathews, R. ve Wacker, W. (2009). Senin Hikâyen Ne. (Çeviren: Aytül Özer). İstanbul: Mediacat.

Mossberg, L. (2008). Extraordinary Experiences Through Storytelling, Scandinavian Journal of Hospitality and Tourism, 8 (3): 195-210.

Pizam, A. (2010). Creating Memorable Experiences, International Journal of Hospitality Management, 29 (3): 343.

Servidio, R. ve Ruffolo, I. (2016). Exploring The Relationship between Emotions and Memorable Tourism Experiences Through Narratives, Tourism Management Perspectives, 20: 151-160.

Tabachnick, B. G. ve Fidell, L. S. (2013). Using Multivariate Statistics. Londra: Pearson Uluslararası Baskı.

Tavşanc1l, E. (2002). Tutumların Ölçülmesi ve SPSS ile Veri Analizi. Ankara: Nobel Yayıncilık.

Tavşancıl, E. (2006). Tutumların Ölçülmesi SPSS ile Veri Analizi (3. baskı). Ankara: Nobel Yayın Dağıtım.
Tekinalp, Ş. ve Uzun, R. (2015). İletişim Araştırma ve Kuramları. İstanbul: Beta Yayınları.

Tivers, J. ve Rakic, T. (2012). Narratives of Travel and Tourism. Londra: Ashgate Publishing.

Tung, V. W. S. ve Ritchie, J. B. (2011). Exploring The Essence of Memorable Tourism Experiences, Annals of Tourism Research, 38 (4): 1367-1386.

Uygur, S. M., Demirer, D. ve Hatırnaz, A. G. B. (2017). Turizm Pazarlamasında Alternatif Bir Araç Olarak Hikâyelerin Kullanımı, Akademik Sosyal Araştırmalar Dergisi, 5 (42): 34-42.

Yilmaz, B. S. (2016). The Impact of Social Media on The Tourist Experience: Telling Your Story to Your Connected Others, Journal of Media Critiques, 2 (8): 133-145.

Zhong, Y. Y. S., Busser, J. ve Baloglu, S. (2017). A Model of Memorable Tourism Experience: The Effects on Satisfaction, Affective Commitment, and Storytelling, Tourism Analysis, 22 (2): 201-217.

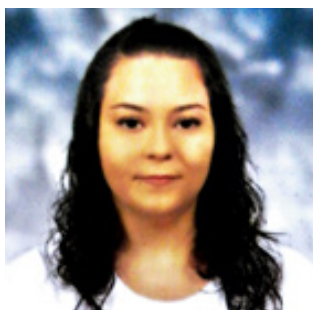

Büşra KAYA

Adnan Menderes Üniversitesi, Seyahat İşletmeciliği Bölümü’nden mezun oldu (2017). Yüksek lisans derecesini Batman Üniversitesi, Turizm İşletmeciliği Dalı'ndan aldı (2020). Halen Ankara Hacı Bayram Veli Üniversitesi, Turizm Işletmeciliği doktora eğitimine devam etmektedir.

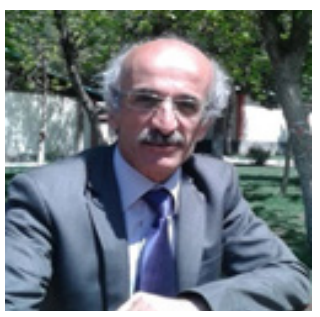

\section{Murat GÜMÜş}

Anadolu Üniversitesi, illetişim Bilimleri Fakültesi'nden mezun oldu (1989). Yüksek lisans derecesini Uludağ Üniversitesi, İșletme Dalı'ndan aldı (1996). Doktora derecesini Uludağ Üniversitesi, İşletme Dalı'ndan aldı (2000). Halen Batman Üniversitesi Turizm ve Otelcilik Meslek Yüksekokulu'nda profesör olarak görev yapmaktadır. Temel çalışma alanları yönetim, davranış ve iletişimdir. 